The Effectiveness of Behavior Modification Using the Fading Technique to Improve the Vocabulary of Deaf Students in SLB-C Negeri Pembina Banjarbaru

Gusti Medinda Ridha Putri, S.Psi ${ }^{\mathrm{a}}$, Rusdi Rusli, M.Psi., Psikolog ${ }^{\mathrm{b}}$, and Jehan Safitri, M.Psi., Psikolog ${ }^{\mathrm{c}}$

${ }^{a}$ Program Studi Psikolog, Lambung Mangkurat, Banjarbaru, Kalimantan Selatan, Indonesia;

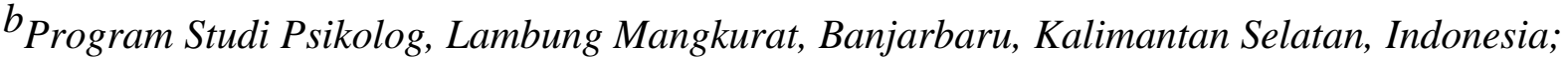
'Program Studi Psikolog, Lambung Mangkurat, Banjarbaru, Kalimantan Selatan, Indonesia

*Corresponding author:

Jehan Safitri, M.Psi., Psikolog

Program Studi Psikolog

Universitas Lambung Mangkurat,

Banjarmasin, Kalimantan Selatan

Indonesia

Email address: jehansafitri@yahoo.com 


\title{
The Effectiveness of Behavior Modification Using the Fading Technique to Improve the Vocabulary of Deaf Students in SLB-C Negeri Pembina Banjarbaru
}

\begin{abstract}
Various problems can arise when individuals interact with individuals with disabilities, especially when one of them is deaf. Being deaf and having hearing loss are conditions in which the individual loses hearing function completely or partially. Generally, the problem faced by an individual when interacting with the deaf is the difficulty communicating because the deaf are unable to communicate well, which is caused by obstacles in language development. The delayed language development of the deaf is preceded by the limited number of vocabulary words known by individuals with hearing loss, result in a delay in learning the structure of sentences. Developing an intervention program to improve the vocabulary of the deaf is critical, and it can be applied to the deaf as early as possible to develop deaf communication skills and address the problems of individuals or other parties who interact directly with the deaf. This research uses the fading technique, one of the behavior modification techniques used by reducing the prompt bit by bit until the prompt is no longer needed to reach the learning goal. Fading in this study was conducted by applying fading to the writing and verbal prompt given while teaching a new vocabulary word to the subject. An intervention program using a flash card and a name card was performed for 1 month, once per week, with a maximum duration of 60 minutes per meeting. This study aims to assess the effectiveness of behavior modification using the fading technique to improve the vocabulary of deaf students in SLB-C Negeri Pembina Banjarbaru. The sampling technique used in this study was purposive sampling, and the criteria were children who have a severe level of hearing loss and have the ability to recognize letters and writing. Based on the sampling process implemented, three subjects were obtained, namely, Al aged 9 years, $\mathrm{N}$ aged 10 years, and Am aged 9 years. The data collection technique was conducted using observation and interview techniques. Observation was performed by observing the subject's vocabulary knowledge before and after the given intervention program, and the interview was conducted with the parents and the teacher of the subject to obtain a general description of the subject. The data collected through observations before and after the intervention program were analyzed using the Wilcoxon signed-rank test, and this test was supplemented by other analyses using categorization, gain scores, and a comparison of subject's average before and after the application of the intervention program. Based on the Wilcoxon signed-rank test analysis, the value of $\mathrm{Z}$ arithmetic was equal to $-1,604$, and through a calculation using a significance level equal to 0,1 a $Z$ table equal to 0,05 was obtained, which means it has a point of coordinate 0,13 . Having created a normal curve with a $\mathrm{Z}$ arithmetic point and a $\mathrm{Z}$ table to enforce the hypothesis, an observation is that the score of the $\mathrm{Z}$ arithmetic is in the rejection rate of $\mathrm{H}$. Categorization was performed on the subject's pretest and posttest score: $\mathrm{Al}$ scored 1, N scored 4, and Am scored 6; thus, all the pretest results of all the subjects were in the low category. During the posttest, Al scored 21, N scored 30, and Am scored 22; thus, all the am posttest results of the three subjects were in the high category. The gain scores were as follows: Al scored 20, $\mathrm{N}$ scored 26, and Am scored 16. The mean of the pretest score was 3,67 and increased to 24,33 on the posttest. Based on the results of this study, a conclusion is that the behavior modification using the fading technique is effective to improve the vocabulary of deaf students at SLB-C Negeri Pembina Banjarbaru.
\end{abstract}


Keywords: behavior modification, fading, vocabulary, deaf

\section{Introduction}

Various problems can arise when individuals interact with individuals with disabilities, for example, when one of whom is deaf. Hearing loss or hearing impairment is a condition where the individual loses hearing function in such a manner that the individual cannot capture various stimuli, especially through the sense of hearing (Somantri, 2012). Mangunsong (2014) classified deafness based on severity, namely, mild hearing loss is between 20 and $40 \mathrm{~dB}$, moderate hearing loss is between 41 and $60 \mathrm{~dB}$, severe hearing loss is between 61 and $90 \mathrm{~dB}$, profound hearing loss is between 91 and $120 \mathrm{~dB}$, and total hearing loss is more than $120 \mathrm{~dB}$.

An inter-census population survey of the Indonesian population in 2015 described 6,952,797 Indonesians aged 10 years and over who have experienced hearing loss, including 178,613 residents who were deaf, 1,180,722 residents with severe hearing loss, and 5,593,462 residents with mild hearing loss category. The survey was also conducted at the provincial level. In the province of South Kalimantan, there were 78,348 people aged 10 years and over who experienced hearing loss, including 2,090 residents who were deaf, 11,562 residents with severe hearing loss, and 64,732 residents with mild hearing loss category (Badan Pusat Statistik, 2015).

Santrock (2010) asserted that deaf people from birth and after birth tend to be weak in speaking and language skills because they do not have media to develop their social, emotional, and intellectual aspects. Somantri (2012) mentioned that in the social aspect, people with hearing loss feel anxiety and experience conflict, confusion, and fear because they face a diverse environment of communication. Regarding the emotional aspect, people with hearing loss have difficulty understanding spoken or written language, which often causes the individual to misinterpret something; thus, the individual feels emotional pressure, which is usually manifested through an attitude of self-closing, acting aggressively, and showing confusion.

Sugiarti (2015) asserted that $5^{\text {th }}$ grade of deaf students in SLB (more than $85 \%$ ) had difficulties with vocabulary mastery and correctly pronouncing Indonesian vocabulary. Parmawati, Prasetyawati, and Prianto (2015) asserted that the delay in language development of deaf children begins with the limited number of vocabularies known by these children, resulting in delays in learning sentence structure. Based on this explanation, an observation is that people with hearing impairment have difficulty in mastering vocabulary; thus, people with a hearing impairment must be able to improve their vocabulary so that they can develop when studying sentence structure.

Psychologist has a special approach to applying learning methods to individuals with special needs. Rusch (in Miltenberger, 2012) asserted that behavior modification has a major role in developing teaching methods in special education. One behavior modification technique is 
fading. Miltenberger (2012) asserted that fading is a gradual elimination of the prompt because behavior consistently appears during the presence of a stimulus. With fading, the stimulus no longer depends on the prompt to bring about the expected behavior.

An example of the application of the fading technique is as follows. A teacher helps one of the students improve her or his vocabulary with the help of a flash card on which there is a picture and description of the name of the picture, for example, a picture of a car (as a flash card) and the word "car."

Car flash cards with the word car act as a stimulus that produces the desired behavior, that is, students can say simple vocabulary words, such as the word car, and finally receive praise from the teacher. When students do not show the desired behavior by not responding when the teacher shows a car flash card, the teacher provides encouragement with a verbal prompt by saying the word "car" when showing the car flash card; thus, that student can say "car" (Miltenberger, 2012).

Furthermore, the fading technique is conducted by gradually eliminating the prompt given by the teacher. For example, the car flash card is shown to the student with several attempts. These attempts start with reducing the prompt until the prompt is eliminated by showing only the car flash card; notably, the student will still able to say "car," and finally, the stimulus can produce the expected behavior without prompts (Miltenberger, 2012).

Two studies in Indonesia have used fading techniques to improve vocabulary, namely, "Application of Behavior Modification Procedures with Token Economy and Fading Techniques to Increase the Vocabulary of Autistic Children in Dorkas Kakas SLB" by Punusingon, Nurhamidin, and Dapa (2013) and "The Effectiveness of Behavior Modification Approach with Fading and Token Economy Techniques to Increase the Vocabulary of Prelingual Profound Deaf student" by Parmawati et al. (2015). Based on the two studies that have been conducted, the fading technique is effective for increasing vocabulary.

Researchers have conducted a preliminary study of subjects comprising three deaf students in the SLB-C Negeri Pembina Banjarbaru. The preliminary study was conducted using the method of observation and interview with Mrs. B, the subject's teacher, and the subject's parents. All the subjects were students the in $3^{\text {rd }}$ grade, deaf, and in class B (a specifically deaf class) at SLB-C Negeri Pembina Banjarbaru. The three subjects were Am, a female aged 8 years; $\mathrm{N}$, a female aged 10 years; and $\mathrm{Al}$, a male aged 9 years.

The preliminary study was conducted on October $26^{\text {th }}, 2017$. The three subjects were observed to be active, able to communicate with researchers by reading lip movements that were sometimes supplemented with sign language, and able to read per syllable. When speaking, the three subjects were able to produce words that could not be heard clearly. The three subjects seemed to communicate more easily than other students in class B because these other students were able to produce only vowels accompanied by very slow intonation or even shouting, which made communication difficult except when using sign language. 
The teacher asserted that different methods have been used to introduce a word related to a subject: The teacher had presented the object in question with lips and a clear voice and had also shown pictures. The teacher explained that showing pictures to the subject often resulted in the subject being unable to recognize the actual object because it was different from the picture shown, but showing pictures was the easiest method to implement. Parents also had difficulties introducing words, and the only means parents used to introduce words is showing the object directly.

Based on the aforementioned explanation, researchers have been interested in applying behavior modification using fading technique to improve vocabulary in deaf students. This study focuses on improving vocabulary through the identification of vocabulary. Notably, because the subjects have limitations when speaking, the indicator of success in this study is the subjects' process of identifying the vocabulary that can be correctly done and written by the subject, instead of pronunciation. The vocabulary introduced to the subjects is a noun on a list of sight words. Sight words are a type of vocabulary that children easily recognize, are very common, and need to be introduced from the beginning because it is the basis of reading.

\section{Methods}

The research design used in this experiment was quasi-experimental. Jones and Forshaw (2012) mentioned that a quasi-experiment is a type of research very similar to actual experiments that does not have all the characteristics required in actual experiments. A quasiexperiment is experimental research that includes several types of interventions or treatments and provides an overview of the comparison; however, the level of control in this type of experiment is insufficient to be classified as an actual experiment. The quasi-experimental design used in this study is one-group pretest-posttest design, that is, the research is conducted by measuring the behavior of a group before and after the treatment given in the experiments (Shaughnessy, E. B. Zechmeister, \& J. S. Zechmeister, 2011).

Seniati, Yulianto, and Setiadi (2009) mentioned that in the one-group pretest-posttest design, at the beginning of the treatment, the first step is the measurement of the dependent variable possessed by the subject; after the treatment is given, the second measurement of the dependent variable is performed by using the same measuring instrument. The effectiveness or influence of the independent variable on the dependent variable can be observed through the difference between the pretest and posttest results. If the posttest result is higher than the pretest, a conclusion is that the independent variable (in the form of treatment) can increase the dependent variable. This study used this design to conduct a comparison before and after the given the behavior modification treatment, namely, the fading technique, by comparing the pretest and posttest scores of one subject group that comprised three deaf students.

The sampling technique in this study uses purposive sampling technique. Sugiyono (2011) mentioned that purposive sampling is the technique used to determine the sample in a study based on certain considerations that are suitable for research and do not have to be 
generalized. This technique is used because researchers need subjects with the same criteria so that the program provided can be accepted by all subjects. The criteria for the subjects in this study were as follows: severe level hearing loss (i.e., 61-90 dB) and the ability to recognize letters and writing.

In this study, the intervention program was conducted using flash cards and name cards. The intervention program was conducted over four, 60-minute meetings to teach 15 new vocabulary words: "punggung," "kasur," "perahu," "kursi," "jagung," "boneka," "pintu," "api," "lantai," "kertas," "babi," "cincin," "domba," "tupai," "jendela."

The steps for each meeting session are as follows:

- Stimulus (flash card) + complete prompt (full writing of the object's name on the name card, and the full verbal prompt of the object's name on the name card from the researcher) $\rightarrow$ The subject was asked to write the name of the object on the flash card $\rightarrow$ If the first step was successful, the subject was given social reinforcement, if unsuccessful, this step was repeated.

- Stimulus (flash cards) + fading prompt (half of the object's name on the name card and some verbal prompts) $\rightarrow$ The subject was asked to write the name of object on the flash card $\rightarrow$ If the second step was successful, the subject was given social reinforcement, if unsuccessful, the sequence was started again with first step.

- Stimulus (flash cards) + fading prompt (the first letter of the name of the object on the flash card, and the verbal prompt by pronouncing the first letter of the object's name from the researcher) $\rightarrow$ The subject will be asked to write the name of object on the flash card $\rightarrow$ If the third step is successful the subject was given social reinforcement, if it is not successful back to the second step.

- Stimulus (flash card) without prompt $\rightarrow$ The subject is asked to write the name of object on the flash card $\rightarrow$ If the last step was successful, the subject was given social reinforcement, if unsuccessful, the steps 1, 2, and 3 are repeated (depending on the subject's ability).

Data collection techniques used in this study were observation, interview, and audiometry test. Observation was the main technique, and the interviews and audiometry tests were for collecting complementary data, namely the general description of all the subjects, which was obtained by interviewing the subject's parents and the teacher. The audiometry tests were performed to confirm the level of the subject's hearing loss.

The researchers performed observations and used a checklist on paper to facilitate the process. The same tests were used for the pretest and posttest and contained new vocabulary words that the subject had to learn. When a subject wrote the new vocabulary, the researcher scored the task as 1 for the correct answer and 0 for the wrong answer. Research data obtained from the pretest and posttest results were analyzed using the Wilcoxon signed-rank test. As mentioned by Riadi (2016), if the value of $\mathrm{Z}$ is in the rejection of $H_{0}, H_{0}$ is rejected; thus, the fading 
technique can improve the vocabulary of deaf students (there are differences in the vocabulary of the deaf students before and after the application of the technique fading).

Validity testing used in this study used content validity by using expert judgment. Azwar (2012) asserted that expert judgment is the agreement of several experts competent in their field, and if most of the experts agree, the scale item on the research measuring instrument is relevant, and the item is then feasible to be used as a measuring instrument in research. The item in this study is 15 vocabulary words that had been assessed by four experts: two clinical, development, and education psychologists, and two teachers for students with special needs at SLB-C Negeri Pembina Banjarbaru.

Reliability in this study was conducted using inter-rater reliability techniques. Azwar (2012) observed that researchers use rating techniques, namely, the procedure of scoring based on subjective judgments on certain aspects or attributes, which are conducted by direct or indirect observation. To minimize the influence of subjectivity on the scoring, the assessment procedure is conducted with more than two people, and this assessment process is referred to as inter-rater reliability. In this study, two assessors, namely, two psychology students of the University of Mangkurat in their $8^{\text {th }}$ semester, also acted as observers. The assessors were provided instructions on the scoring procedure. Regarding the implementation of inter-rater reliability, the total number of observers in this study was three, namely, one of the researchers and two other observers, so that the observations of the researcher could be easily compared with the results of the other observers.

\section{Result}

This research was conducted for approximately 1 month: April 1 to April 25, 2018. In this study, the measured data was data from the results of the pretest and posttest and was categorized according to the research categorization that has been determined. Table 1 presents the data categorization of the pretest results of the three subjects:

Table I. Distribution of Data Categorization (Pre-Test)

\begin{tabular}{|c|l|l|l|l|}
\hline Variable & Value Range & \multicolumn{1}{|c|}{ Category } & $\begin{array}{c}\text { Frequenc } \\
\text { y }\end{array}$ & \multicolumn{1}{|c|}{ Percentage } \\
\hline \multirow{2}{*}{$\begin{array}{l}\text { Vocabulary } \\
\text { Knowledge }\end{array}$} & $0<10$ & Low & 3 & $100 \%$ \\
\cline { 2 - 5 } & $10<20$ & Medium & - & - \\
\cline { 2 - 5 } & $20-30$ & High & - & - \\
\hline
\end{tabular}

In Table 1, all subjects are in the low category; thus, all subjects have low vocabulary knowledge. Table 2 presents the categorization of the data of posttest results of three subjects:

Table II. Distribution Data Categorization (Post-Test)

\begin{tabular}{|c|l|l|l|l|}
\hline Variable & \multicolumn{1}{c|}{$\begin{array}{c}\text { Value } \\
\text { Range }\end{array}$} & \multicolumn{1}{|c|}{ Category } & Frequency & Percentage \\
\hline \multirow{2}{*}{$\begin{array}{l}\text { Vocabulary } \\
\text { Knowledge }\end{array}$} & $0<10$ & Low & - & - \\
\cline { 2 - 5 } & $10<20$ & Medium & - & - \\
\cline { 2 - 5 } & $20-30$ & High & 3 & $100 \%$ \\
\hline
\end{tabular}


In Table 2, all subjects are in the high category; thus, all subjects have a high vocabulary knowledge. Table 2 also shows that after the implementation of the intervention program to improve vocabulary using the fading technique, all subjects experienced increases. In the beginning, the pretest scores indicated that all the subjects were in the low category; at the end of the study, the posttest scores increased to the high category.

This result is in accordance with the assertion from Parmawati et al. (2015): behavior modification approaches with a token economy and fading techniques are effective at increasing vocabulary in prelingual profoundly deaf learners. Parmawati et al. (2015) combined token economy techniques and fading to improve the vocabulary of deaf students, but this study concluded that the fading technique can also be effective for improving the vocabulary of deaf students.

In the three subjects, differences were observed between the pretest and the posttest results (gain score), which are addressed in Table 3:

Table III. Subjects' Gain Score on Pre-Test and Post-Test

\begin{tabular}{|l|l|l|l|l|l|}
\hline No. & Name & Gender & Pretest & Posttest & Gain Score \\
\hline $\mathbf{1}$ & $\mathrm{Al}$ & $\mathrm{L}$ & 1 & 21 & 20 \\
\hline $\mathbf{2}$ & $\mathrm{N}$ & $\mathrm{P}$ & 4 & 30 & 26 \\
\hline $\mathbf{3}$ & $\mathrm{Am}$ & $\mathrm{P}$ & 6 & 22 & 16 \\
\hline
\end{tabular}

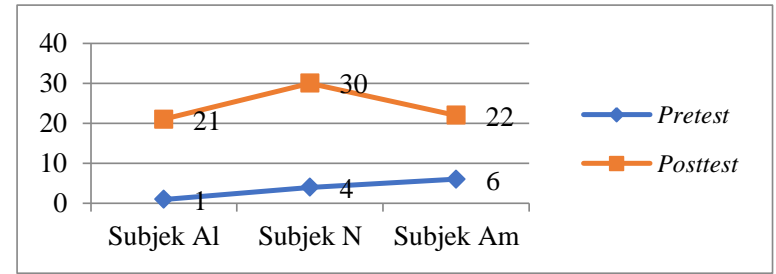

Fig. 1. Comparison Graph of Subjects' Pretest and Posttest Result

Data were obtained during the pretest and posttest and then analyzed by using the Wilcoxon signed rank to assess if the two samples were paired, but in only the control group. The two paired samples in this study were the results of pretest and posttest for the subjects, and for the control group, the three subjects of the study. In carrying out the signed Wilcoxon-rank test, the researcher compared the calculated $\mathrm{Z}$ and $\mathrm{Z}$ table value. When the value of calculated $\mathrm{Z}$ was in the rejection area of $H_{0}, H_{\mathrm{a}}$ was accepted, and vice versa. Table 4 presents the results of the $\mathrm{Z}$ count obtained with the help of the IBM SPSS Statistics 23 computer program:

Table IV. Result of Wilcoxon Signed-Rank Test

\begin{tabular}{|l|c|c|l|l|}
\hline \multicolumn{2}{|c|}{} & N & $\begin{array}{c}\text { Mean } \\
\text { Rank }\end{array}$ & Sum of Ranks \\
\hline \multirow{3}{*}{ Pretest - Posttest } & Negative Ranks & 0 & 0,00 & 0,00 \\
\cline { 2 - 5 } & Positive Ranks & 3 & 2,00 & 6,00 \\
\cline { 2 - 5 } & Ties & 0 & & \\
\hline & Total & 3 & & \\
\hline
\end{tabular}




\begin{tabular}{|c|c|l|l|l|}
\hline Z & $-1,604$ & & & \\
\hline $\begin{array}{c}\text { Asymp. Sig (2- } \\
\text { tailed) }\end{array}$ & 0,109 & & & \\
\hline
\end{tabular}

In this analysis, the value considered is the $\mathrm{Z}$ value with $\alpha=0.1(10 \%)$. If calculated $\mathrm{Z}$ is in the reception area of $H_{0}, H_{0}$ is accepted, and if calculated $\mathrm{Z}$ is outside the reception area $H_{0}, H_{0}$ is rejected. The formula for calculating $\mathrm{Z}$ tables is as follows:

$$
\begin{gathered}
\alpha-\frac{\alpha}{2} \\
0,1-\frac{0,1}{2} \\
0,1-0,05 \stackrel{0}{=} 0,05
\end{gathered}
$$

The $\mathrm{Z}$ table value obtained is 0.05 , which means it has a coordinate point of 0.13 when referring to a $\mathrm{Z}$ table for a normal curve. Based on the value of calculated $\mathrm{Z}$ and the $\mathrm{Z}$ table that has been obtained, an observation is that the value of calculated $Z(-1.604)$ is in the region of rejection of $H_{0}$. The results of this statistical analysis are illustrated in Figure 2:

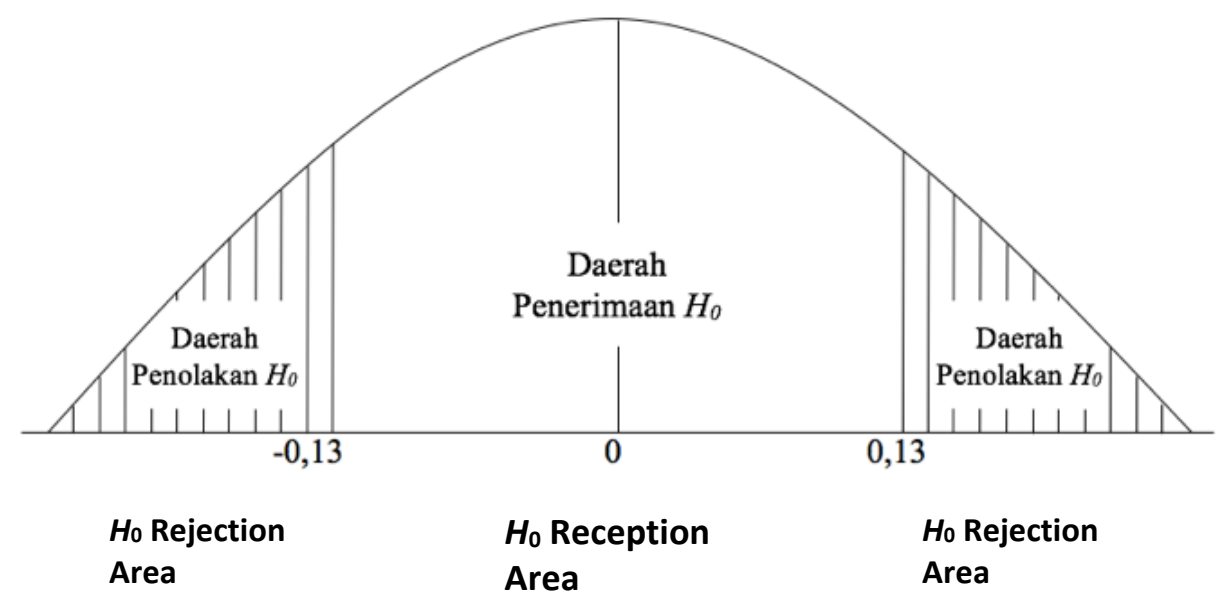

Fig. 2. Rejection and Reception Area of H0

The results of the analysis using the Wilcoxon signed-rank test indicate that the calculation of the value of the $\mathrm{Z}$ count of -1.604 is in the rejection area of $H_{0}$ after making a curve with the $\mathrm{Z}$ coordinates of the table by 0.13 . This result means that there are differences in vocabulary in the subject before and after the implementation of the fading techniques. From the several analyses that were performed, a conclusion is that there are differences that lead to an increase in the subjects' vocabulary knowledge before and after the subject is given treatment using the fading technique.

\section{Discussion}

This discussion also answers the research question by providing results that indicate that the implementation of behavior modification using fading techniques is effective to improve vocabulary in deaf students of SLB-C Negeri Pembina Banjarbaru. Parmawati et al. (2015) 
used fading techniques to increase the vocabulary of deaf subjects diagnosed with a profound level of hearing loss. Based on the results of this study, the fading technique can also be effectively applied to improve the vocabulary of deaf subjects with a severe level of hearing loss.

Fading techniques can be applied effectively and cannot be separated from the age factor of all the subjects, who were in late childhood. Santrock (2011) asserted that in middle and late childhood, there is an increase in memory that reflects an increase in knowledge in children. The task of the subject in the application of this intervention program is to remember the new vocabulary shown through a flash card; because of the process of improving memory in late childhood, the subject is helped to complete the task to remember the new vocabulary.

There is a unique dynamic between one subject and another subject. Am subjects were aged 8 years, and an increase in vocabulary knowledge scores was observed after the intervention program implementation of 16 . Subjects aged 9 years obtained an increase in vocabulary knowledge scores after the intervention program implementation of 20. Subject $\mathrm{N}$ was 10 aged years and an increase in vocabulary knowledge scores was observed after the application of the program intervention amounted to 26 . When observed carefully, the increase that occurred was greater in the subjects older than the other subjects. This result can be understood by referring to Santrock (2011), who asserted that older children compared with younger children are usually more skilled and have a better memory.

In this study, if the subject cannot complete the steps in the fading technique, it is repeated in the previous stage until the subject makes no mistakes. The repetition conducted in this study is in accordance with the memory method. Febriana, Rahmah, and Erlyani (2012) asserted that the memory method is a method of memory research that examines the extent of the time needed by the subject to be able to master material that is well studied. More specifically, the repetition method is a type of memory method, which is a method of re-learning. The relearning method asserts that the more often material is learned, the more material that can be remembered well, and the less material is forgotten.

When implementing the intervention program in this study, the researchers used social reinforcement as an amplifier. Sometimes when implementing an intervention program, the subject looked upset and wanted to give up when mistakenly remembering the vocabulary at a certain step; in this situation, the researchers always provided support and encouragement so that the subject would continue to attempt to remember the new vocabulary the subject is learning. In addition, the researchers always provided positive social reinforcement when the subject was able to remember the new vocabulary well and avoided negative reinforcement or punishment when the subject could not remember the new vocabulary. Social reinforcement is a type of reinforcement effective in facilitating the successful implementation of intervention programs. Martin and Pear (2015) stated that one of the social reinforcers in the form of attention from others is a very strong amplifier for almost everyone. One example of social reinforcement is praise, which is positive and effective reinforcement used to strengthen and maintain appropriate behavior in everyday life. 
This study has limitations. The first limitation is a higher significance value of 0.009 than the initial significance value that had been determined; this was likely due to the limited number of subjects in this study, namely, three subjects. In addition, it is difficult to find subjects with the same level of hearing loss; if the subject does not have references as a reference level of the hearing loss experienced by the subject, the researcher must perform audiometry tests on several children to find children with the same hearing loss level that matches the research subject category. Additionally, the researchers observed that the obstacles to implementing the intervention programs were substantial because building communication with children with special needs, especially deaf children, is different from that process with normal children; thus, the researchers realized that they required a higher level of competence to be able to maximize the application of intervention programs in this study.

\section{Conclusion}

Based on the categorization of data, an observation is that after the implementation of the intervention program, all the subjects' scores increased. Initially, in the pretest stage, all the subjects were in the low category; then, in the posttest stage, all the subjects were in the high category. The gain score obtained by Al, N, and Am was 20,26, and 16, respectively. The comparison of mean shows an average increase of 20.66 in the posttest value of all subjects compared with the pretest value, which means that the subjects' vocabulary knowledge was higher after the treatment (i.e., applying fading techniques to improve vocabulary). The Wilcoxon signed-rank test demonstrated that the significance level was 0.109 , which is greater than 0.009 from the level of significance of the research previously determined by 0.1 . Nevertheless, the research that remains rejected the $H_{0}$ and referred to the value of calculated $\mathrm{Z}$ research is -1.604 , and the value of the $\mathrm{Z}$ table is 0.13 , which means the value of calculated $\mathrm{Z}$ is in the region of rejection of $H_{0}$, which means $H_{\mathrm{a}}$ is accepted. Based on several analysis techniques conducted by the researchers to answer the research questions, a conclusion is that the behavior modification using the fading technique is effective to improve vocabulary in deaf students of SLB-C Negeri Pembina Banjarbaru.

\section{References}

Azwar, S. (2012). Reliabilitas dan validitas. Yogyakarta: Pustaka Belajar Offset.

Badan Pusat Statistik. (2015). Penduduk indonesia: Hasil survei penduduk antar sensus (Nomor Publikasi No. 04110.1541).

Retrieved from https://www.bps.go.id/publication/2015/11/23/9de128fbeea9ae5bd40914d0/pendudukindonesia-hasil-survei-penduduk-antar-sensus-2015.html

Febriana, S.K.T., Rahmah, D.N., Erlyani, N. (2012). Psikologi umum: Konsep dasar. Banjarbaru: Zifatama.

Jones, S., Forshaw, M. (2012). Research methods in psychology. London: Pearson Education Limited.

Mangunsong, F. (2014). Psikologi dan pendidikan anak berkebutuhan khusus jilid kesatu. Depok: Lembaga Pengembangan Sarana Pengukuran dan Pendidikan Psikologi Universitas Indonesia

Martin G., Pear, J. (2015). Modifikasi perilaku: makna dan penerapannya. Yogyakarta: Pustaka Pelajar Miltenberger, R. G. (2012). Behavior Modification: Principle \& Procedures. USA: Cengage Learning.

Parmawati, S. B., Prasetyawati, W., Prianto, R. M. A. (2015). Pendekatan modifikasi perilaku dengan teknik fading dan tokeneconomy untuk meningkatkan kosakata siswa tunarungu prelingual profound. Psibernetika, 8(1), 19-34. 
Punusingon, L. N., Nurhamidin, S., Dapa, A. (2013). Penerapan prosedur modifikasi perilaku dengan teknik fading dan token economy untuk meningkatkan kosakata anak autis di slb dorkas kakas. Jurnal Fakultas Ilmu Pendidikan, 2(3), 11-21.

Riadi, E. (2016). Statistika penelitian (analisis manual dan ibm spss). Yogyakarta: Penerbit ANDI.

Santrock, J. W. (2010). Psikologi pendidikan. Jakarta: Kencana.

Santrock, J. W. (2011). Masa perkembangan anak edisi 11 buku 2. Jakarta: Salemba Humanika.

Seniati, L., Yulianto, A., Setiadi, B. N. (2009). Psikologi eksperimen. Jakarta: PT Indeks.

Shaughnessy, J. J., Zechmeister, E. B., Zechmeister, J. S. (2011). Research methods in psychology. New York: McGraw-Hill.

Somantri, S. (2012). Psikologi anak luar biasa. Bandung: PT. Refika Aditama.

Sugiarti, S. (2015). Upaya meningkatkan kosakata anak tunarungu melalui media variasi gambar pada siswa kelas v/b di slb negeri surakarta. Prosiding Ilmu Pendidikan, 1(2), 254-260.

Sugiyono. (2011). Metode penelitian kuantitatif, kualitatif dan $r \& d$. Bandung: Alfabeta. 